論 文

Original Paper

\title{
湿式亜鉛製鍊工程におけるシリカの基礎的挙動について*
}

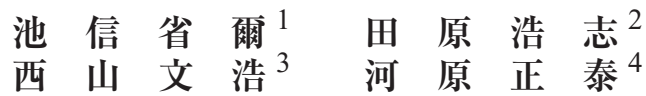

\section{Behavior of Silica in the Zinc Refinery Process}

\author{
by Seiji IKENOBU ${ }^{\mathrm{a}}$, Koji TAHARA ${ }^{\mathrm{b}}$, Fumihiro NISHIYAMA ${ }^{\mathrm{c}}$ and Masayasu KAWAHARA ${ }^{\mathrm{d}}$
}

a. Mitsui Mining \& Smelting Co., Ltd. Corporate Management Division Tokyo 141-8584 Japan

(Corresponding author E-mail: s_ikenobu@mitsui-kinzoku.co.jp)

b. Graduated School of Science and Technology, Kumamoto University, Kurokami, Kumamoto 860-8555, Japan (At present: Daido Steel Co., Ltd.)

c. Graduate School of Science and Technology, Kumamoto University

d. Graduate School of Science and Technology, Kumamoto University, Professor

In recent year, it is necessary to treat imported ore in zinc hydrometallurgy because of stable demand of material and depletion of domestic mine. However, the imported ore often contains a lot of impurities. Among them, $\mathrm{SiO}_{2}$ complicates solid-liquid separation after leaching process. The cause of this degradation is understood that $\mathrm{Zn}_{2} \mathrm{SiO}_{4}$ produced in roasting process is leached in leaching process, and then supersaturated silica solves in solution. In previous research, it was reported that solid-liquid separation was improved by increasing of $\mathrm{pH}$ and temperature, and seed method was effective for reducing $\mathrm{SiO}_{2}$ concentration. However, mechanism of the solidliquid separation improvement hasn't been well understood. The purpose of this paper is to obtain the knowledge for the effects of temperature, $\mathrm{pH}$ and impurities on silica polymerization.

(1) Solution temperature influences the colloidal silica polymerization, and the polymerization is promoted as the temperature is elevated.

(2) In the solution of $\mathrm{pH}$ range from 1 to 3 , the polymerization rate is almost the same. When $\mathrm{pH}$ is raised to 4 , the polymerization rate has been promted.

(3) Hydrolysis reaction of $\mathrm{Fe}$ and $\mathrm{Al}$ influences the decreasing of $\mathrm{SiO}_{2}$ concentration by rising $\mathrm{pH}$ in field test.

(4) Addition of silica seed has greatly reduced the ionic and colloidal silica in the solution.

KEY WORDS: Zinc Refinery, Silica, Zinc Silicate, Solid-liquid Separation, Colloid, Gel

\section{1. 緒言}

日本国内の亜鉛鉱山は，2006 年豊羽鉱山を最後にすべて閉山 した。その結果現在の国内製錬所は，主な原料として海外鉱を使 用している。そのため不純物の品位は, 経験のないレベルまで上 昇している。著者らは，鉱石中のシリカに注目した。

亜鉛精鉱に混入しているシリカは，焙焼炉において $\mathrm{Zn}_{2} \mathrm{SiO}_{4}$ を 生成する。 $\mathrm{Zn}_{2} \mathrm{SiO}_{4}$ は硫酸酸性溶液に容易に溶解する。溶出した シリカは処理方法を誤るとゲル化し，固液分離特性を悪化させる ことがわかっている。このため溶出したシリカを固液分離の容易 な形態で沈殿させる技術が必要になる。この解決策としては，い くつかの方法が提案されている1-5)。しかしながら，シリカの沈 殿反応に及ぼす諸因子の影響は明確にされていない。

そこで本研究では, シリカをイオン状シリカとコロイド状シリ

*2007 年 7 月 27 日受付 12 月 8 日受理

1. 普通会員 三井金属鉱業 (株) 経営企画部

2. 熊本大学大学院生 自然科学研究科 マテリアル工学専攻（現 大同 特殊鋼 (株))

3. 熊本大学大学院生 自然科学研究科 マテリアル工学専攻

4. 普通会員 工博 熊本大学教授 自然科学研究科 マテリアル工学専攻

[ 著者連絡先 ] FAX: 03-5437-8074 (三井金属・池信) E-mail: s_ikenobu@mitsui-kinzoku.co.jp

キーワード：亜鉛製錬，シリカ，ジンクシリケイト，固液分離，コロイド, ゲル
カ及び固体シリカに分類し, シリカの沈殿反応に及ぼす諸因子の 影響について調查した。

\section{2. 試料および実験方法}

\section{$2 \cdot 1 \mathrm{Zn}_{2} \mathrm{SiO}_{4}$ 作成}

本実験では，まず溶解試験のための試料作成及び焙焼工程にお ける $\mathrm{Zn}_{2} \mathrm{SiO}_{4}$ の生成に関して速度論的な考察を行うために $\mathrm{Zn}_{2} \mathrm{SiO}_{4}$ を合成した。 $\mathrm{ZnO}$ と $\mathrm{SiO}_{2}$ をモル比 $2: 1$ で混合し, ペレッ 卜状に成形した試料をそれぞれ $1000,1100,1200^{\circ} \mathrm{C}$ の所定温度に 設定した電気炉内で所定時間加熱保持後, 炉内で室温まで放置し た。なお $\mathrm{ZnO}, \mathrm{SiO}_{2}$ は, 酸化亜鉛 (試薬 1 級) , 二酸化珪素 (無 水珪酸, 沈降性, 試薬特級) をそれぞれ使用した。

\section{$2 \cdot 2 \mathrm{Zn}_{2} \mathrm{SiO}_{4}$ への反応率の決定}

$\mathrm{Zn}_{2} \mathrm{SiO}_{4}$ の反応率の決定には X 線回折の内部標準法を用いた。 硫酸溶液中において $\mathrm{ZnO}$ は $\mathrm{pH} 2.5$ 以上 $\left(70^{\circ} \mathrm{C}\right)$ の条件でも浸出さ れるが, $\mathrm{Zn}_{2} \mathrm{SiO}_{4}$ は浸出されない。そこで, この特性を利用し, $1200^{\circ} \mathrm{C}$ で $12 \mathrm{~h}$ 加熱して作成した試料を $\mathrm{pH} 2.8\left(70^{\circ} \mathrm{C}\right)$ の条件で 5 時間浸出試験を行い, 試料中の $\mathrm{ZnO}$ だけを硫酸溶液で浸出させ た。その後, $70^{\circ} \mathrm{C}$ 純水で残渣をリパルプ洗浄し, 得られた浸出 液を ICP 発光分光分析装置によって未反応の $\mathrm{Zn}$ 濃度を定量した。 そして, 分析の結果と加熱前の試料中の $\mathrm{Zn}_{2} \mathrm{SiO}_{4}$ 量から反応率を 


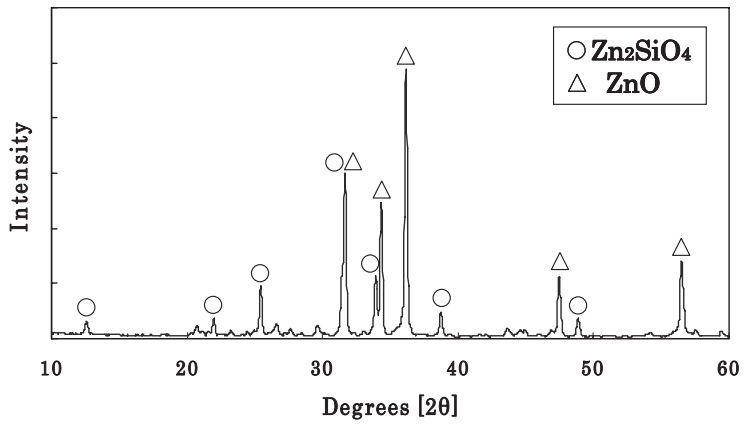

Fig.1 X-ray diffraction pattern of a calcine of zinc refinery.

決定した。さらに，作成した試料に対して $30 \mathrm{wt} \%$ の $\mathrm{Al}_{2} \mathrm{O}_{3}$ を添 加して X 線回折を行い, $\mathrm{Zn}_{2} \mathrm{SiO}_{4}$ の (140) 面の回折ピーク強度 I と内部標準物質である $\mathrm{Al}_{2} \mathrm{O}_{3}$ の (104) 面の回折ピーク強度 Is との 比 I / Is を求め, 反応率とピーク強度比との関係から検量線を 作成した。次に，それぞれ各温度で所定の時間まで加熱した試料 に対しても同様に $30 \mathrm{wt} \%$ の $\mathrm{Al}_{2} \mathrm{O}_{3}$ を添加して X 線回折を行うこ とでI / Is を求め, 前述の方法で作成した検量線を用いて反応 率を決定した。なお未反応の $\mathrm{SiO}_{2}$ はクオーツであり，予察試験 を行いあらかじめ溶存するシリカとの反応に影響の無いことを確 認した。

\section{$2 \cdot 3$ 硫酸浸出}

$2 \cdot 1$ の方法に従い $1200^{\circ} \mathrm{C}$ で焼成した $\mathrm{Zn}_{2} \mathrm{SiO}_{4}$ を硫酸溶液で浸 出を行った。しかしその際, 過去の研究から $\mathrm{Zn}_{2} \mathrm{SiO}_{4}$ は硫酸酸性 浴中において $\mathrm{pH}$ が 2.5 未満でないと溶解しないという報告があ る ${ }^{6)}$ 。そこで, まず, $\mathrm{pH}=1$, 温度 $70^{\circ} \mathrm{C}$ の条件で $\mathrm{Zn}_{2} \mathrm{SiO}_{4}$ を溶 解した。コロイド状イオンその後, 水酸化ナトリウム溶液を加え ることで $\mathrm{pH}$ を $1,2,3,4$ に調整し，ホットスターラーの保温機能 により溶液の温度を $70,90^{\circ} \mathrm{C}$ に調整した。調整後攪汼を行い，そ れぞれ 1, 2, 3, 4 時間ごとに試料をサンプリングした。サンプリン グした試料はN $.5 \mathrm{C}$ のろ紙を用いて吸引ろ過を行った後適宜希 釈し, 試料中の各種シリカ濃度を吸光光度法により定量した。な お初期シリカ濃度は, $\mathrm{Zn}_{2} \mathrm{SiO}_{4}$ の添加量と反応率から計算して求 めた。

\section{$2 \cdot 4$ 金属添加試験}

実操業で処理されている亜鉛焼鉱には Zn 以外にも多くの不純 物が含まれている。そこで, 本実験では不純物がシリカの重合に 及ぼす影響を調査した。対象とする金属元素は湿式覀鉛製鍊の工 程で主に溶液に含まれている $\mathrm{Fe}, \mathrm{Al}, \mathrm{Mg}, \mathrm{Mn}, \mathrm{Ca}$ の 5 種類とし，そ れぞれ $\mathrm{FeSO}_{4} \cdot 7 \mathrm{H}_{2} \mathrm{O}, \mathrm{Al}_{2}\left(\mathrm{SO}_{4}\right)_{3} \cdot 8 \mathrm{H}_{2} \mathrm{O}, \mathrm{MgSO}_{4} \cdot 7 \mathrm{H}_{2} \mathrm{O}, \mathrm{MnSO}_{4}$ ・ $5 \mathrm{H}_{2} \mathrm{O}, \mathrm{CaCl}_{2}$ を $\mathrm{Zn}_{2} \mathrm{SiO}_{4}$ 溶解後に試験溶液に加えることで実験を 行った。また， $\mathrm{Fe} に$ 関しては $\mathrm{FeSO}_{4} \cdot 7 \mathrm{H}_{2} \mathrm{O}$ を溶解したままでは 二価の $\mathrm{Fe}^{2+}$ で存在するため, 過マンガン酸カリウム溶液を加え ることで $\mathrm{Fe}^{2+}$ を $\mathrm{Fe}^{3+}$ に酸化した。

試験後，各種金属濃度をICP-AES にて定量した。

\section{$2 \cdot 5$ 固体シリカ添加試験}

メタケイ酸ナトリウム $\left(\mathrm{Na}_{2} \mathrm{SiO}_{3} \cdot 9 \mathrm{H}_{2} \mathrm{O}\right)$ を純水で溶解する。そ の後溶液の $\mathrm{pH}$ を 4 , 温度を $70^{\circ} \mathrm{C}$ 調整し, $1 \mathrm{~h}$ 攪拌した後溶液を ろ過し, 得られた沈殿物を乾燥した。沈殿物にはナトリウムが付 着している可能性があるため, その沈殿物をさらに $70^{\circ} \mathrm{C}$ の純水 で洗浄した後 No.5Cのろ紙でろ過し， 万紙上に残った沈殿物を 固体シリカとした。添加試験においては，固体シリカを $\mathrm{SiO}_{2}$ と して 40g/L 添加した。

\section{$2 \cdot 6$ モリブデン黄吸光光度法}

溶液中のシリカは, イオン状シリカ, コロイド状シリカ, 固形

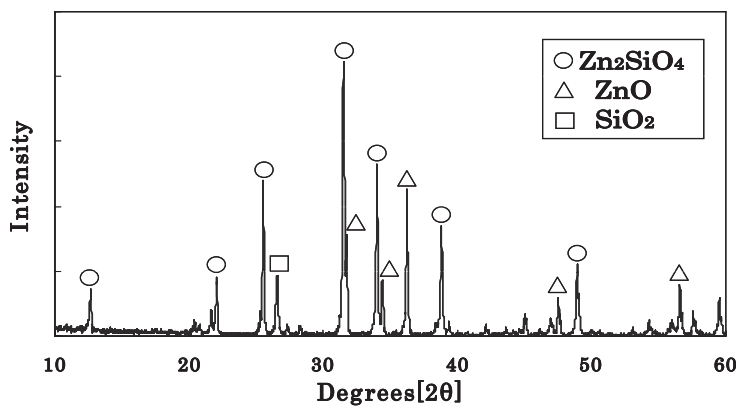

Fig.2 X-ray diffraction pattern of calcine roasted at $1200^{\circ} \mathrm{C}$ for $12 \mathrm{~h}$.

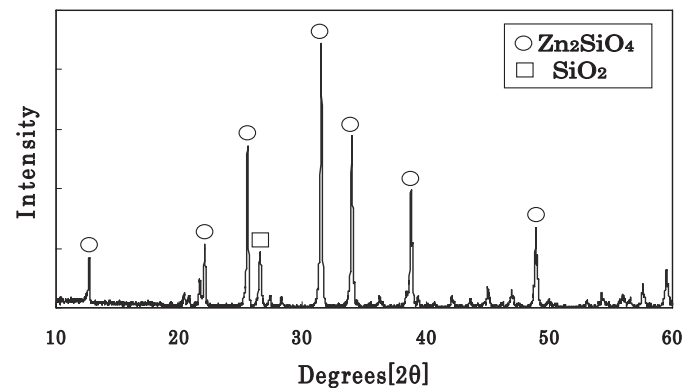

Fig.3 X-ray diffraction pattern of leach residue $\left(\mathrm{pH} 2.8,70^{\circ} \mathrm{C}, 5 \mathrm{~h}\right)$

物シリカに区分される。本実験ではこれら各種形態のシリカを測 定するためにモリブデン黄吸光光度法を用いた。以下に各種シリ カの分析方法及び特徽について示す。なお分析方法は, JIS K0101:199844 を参照した。

（1）イオン状シリカ 試料溶液を No.5C ( 保留粒子径 $1 \mu \mathrm{m})$ のろ 紙を用いてろ過を行った。万過した溶液を $50 \mathrm{ml}$ 採取し, 塩酸 $(1+1)$ $1 \mathrm{ml}$ とモリブデン酸アンモニウム溶液 $(100 \mathrm{~g} / \mathrm{L}) 2 \mathrm{ml}$ とを加えて振 り混ぜ, 5 分間放置する。その後, 波長 $430 \mathrm{~nm}$ の吸光度を測定す ることで濃度を分析した。

（2）コロイド状シリカ No.5 Cのろ紙を用いてろ過した溶液 $100 \mathrm{ml}$ を四フッ化エチレン樹脂製ビーカーにとり，炭酸水素ナ卜 リウムを $0.2 \mathrm{~g}$ 加えた。その後沸騰水浴中に入れ, 20 分間加熱した。 放冷後, 塩酸 $(1+1)$ で中和し $\mathrm{pH}$ を約 5 に調整し, 第 1 項の手順 でイオン状シリカを分析した。この分析で得られた濃度はもとも とイオン状であったシリカを含んだ濃度 (溶存シリカ) であるた め, 第 1 項で測定したイオン状シリカの濃度との差をとることで コロイド状シリカの濃度を得ることができる。

(3) 固体シリカ 浸出したシリカの濃度から溶存シリカの濃度 を差し引くことで濃度を求めた。

\section{3. 結果および考察}

\section{3. $1 \mathrm{Zn}_{2} \mathrm{SiO}_{4}$ の生成}

(1) 亜鉛焼鉱の X 線回折結果 Fig. 1 亿神岡鉱業株式会社亜鉛 製鍊工場で製造された焼鉱の X 線回折結果を示す。主に $\mathrm{ZnO}$ の ピークが見られるが，前述した固液分離特性悪化の原因となる $\mathrm{Zn}_{2} \mathrm{SiO}_{4}$ が生成していることが確認できた。

(2) $\mathrm{Zn}_{2} \mathrm{SiO}_{4}$ 反応率の時間変化 Fig. 2 に $1200^{\circ} \mathrm{C}$ で $12 \mathrm{~h}$ 加熱し た試料，また Fig. 3 にその試料を 2 ・ 2 節に示した pH2.8で, $\mathrm{ZnO}$ のみの浸出試験を行い, そのときに生じた残渣の X 線回折 結果を示す。浸出前と浸出後の結果とを比較すると, 浸出後では $\mathrm{ZnO}$ のピークのみが消えており, $\mathrm{Zn}_{2} \mathrm{SiO}_{4}$ は浸出せずに残渣中に 残っていることがわかる。 


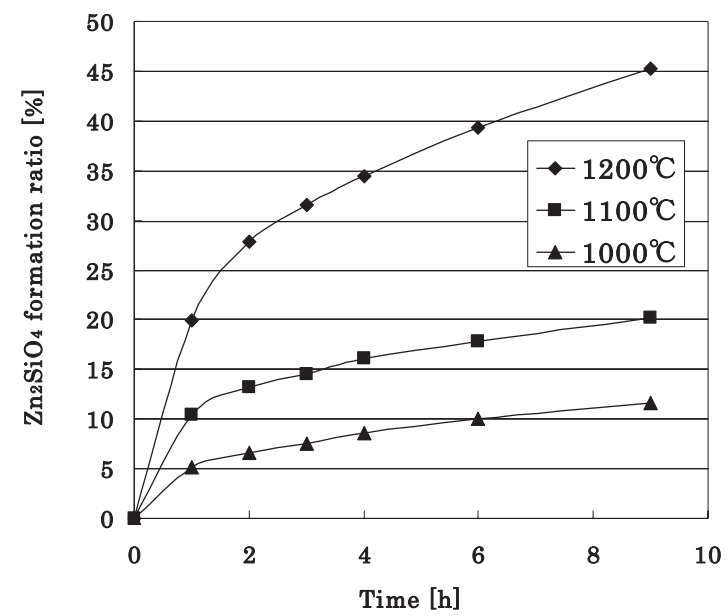

Fig.4 Time-dependence of the formation ratio of $\mathrm{Zn}_{2} \mathrm{SiO}_{4}$ at various temperatures.

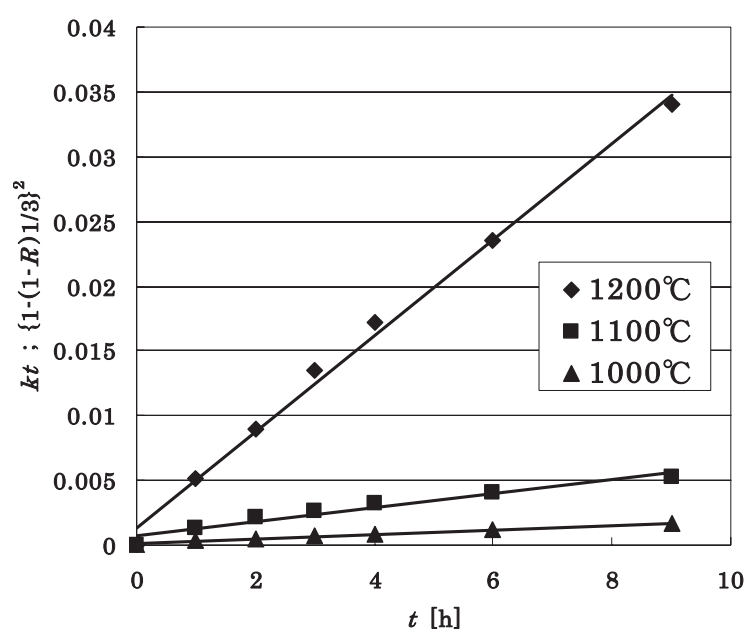

Fig.5 Relation between $k t$ and $t$ calculated by applying Jander's equation.

Fig. 4 に各温度で所定時間加熱保持した試料の保持時間と $\mathrm{Zn}_{2} \mathrm{SiO}_{4}$ 生成の反応率との関係を示す。加熱温度が高いほど反応 率は高くなり, 時間とともにゆるやかに上昇していくことがわかる。 (3) $\mathrm{Zn}_{2} \mathrm{SiO}_{4}$ 生成の速度論的考察本固体反応を考察するため, Janderの提唱した粉末固 - 固反応についてのモデル7)を参考にした。

$$
\left\{1-(1-R)^{1 / 3}\right\}^{2}=k t
$$

$R$; 反応率, $t$; 時間, $k$; 速度定数

上式に本実験での結果を代入して得られた $k t$ と加熱保持時間 $t$ と の関係を示したものが Fig. 5 である。いずれの温度においてもほ ぼ直線となった。そこで次に, 反応速度定数の Arrhenius プロッ 卜から, 反応の見掛けの活性化エネルギーを求めた。直線の傾き から見掛けの反応速度定数 $k$ を求め, この対数 $\log k$ と絶対温度 の逆数 $T^{-1}$ をプロットしたものを Fig. 6 に示す。こちらもほぼ 直線関係が成立したため, この直線の傾きから本固体反応の見掛 けの活性化エネルギーを求めると, 約 $231 \mathrm{~kJ} / \mathrm{mol}$ となった。

\section{$3 \cdot 2$ シリカ沈殿試験}

本実験で行った硫酸浸出によって $\mathrm{Zn}_{2} \mathrm{SiO}_{4}$ が溶解，沈殿する反 応は以下の式で表される。

$$
\mathrm{Zn}_{2} \mathrm{SiO}_{4}+2 \mathrm{H}_{2} \mathrm{SO}_{4} \rightarrow 2 \mathrm{ZnSO}_{4}+\mathrm{Si}(\mathrm{OH})_{4}(\mathrm{aq})
$$

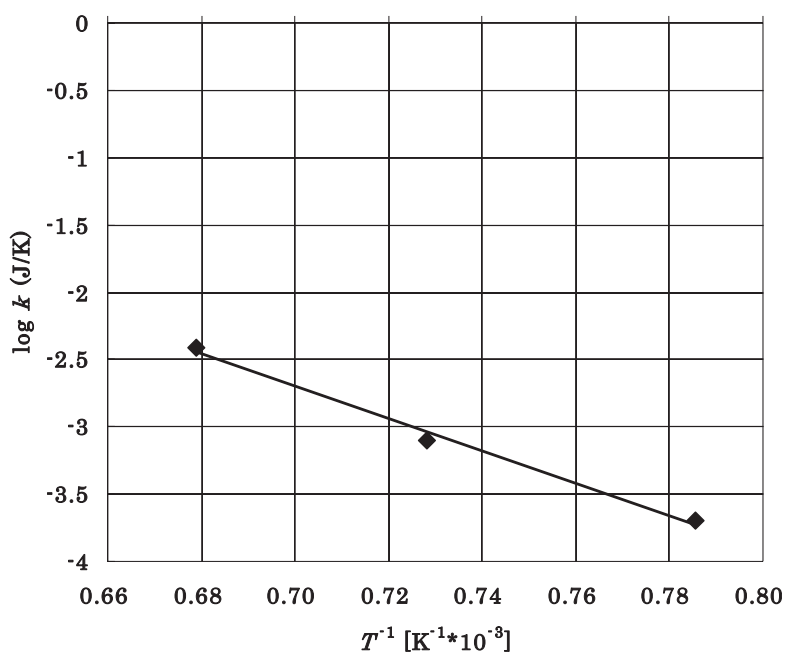

Fig.6 Relation between $\log k$ and $T^{-1}$.

$n \mathrm{Si}(\mathrm{OH})_{4} \rightarrow\left(\mathrm{SiO}_{2}\right) n+2 n \mathrm{H}_{2} \mathrm{O}$

また (1) 式の反応は速やかに進行するが，(2) 式の反応は溶出反 応と比較し緩やかに進行する。前述のように, 溶出したシリカは, 処理方法を誤るとゲル化し固液分離特性を悪化させることがわ かっている。本節においては, 残渣の固液分離特性を向上させる ために, (2) 式の反応に及ぼす諸因子の影響を知ることが重要で あると考え, シリカをイオン状シリカ, コロイド状シリカ, 固体 シリカに分類し, それぞれの濃度变化に及ぼす諸因子の影響を調 查した。

(1) 温度の影響 Fig. 7 に $\mathrm{pH} 3$ における初期シリカ濃度 $4500 \mathrm{mg} / \mathrm{L}$ での溶液の温度が溶液中の各種シリカ濃度の変化に与える影響に ついて示す。イオン状シリカが時間と共に減少し, コロイド状シリ カが増加している。ここで $70^{\circ} \mathrm{C}$ と $90^{\circ} \mathrm{C}$ と比較すると両者に差は ほとんど見られない。しかし Fig. 8 に示すように溶液の $\mathrm{pH}$ が 4 の 場合, $70^{\circ} \mathrm{C}$ と $90^{\circ} \mathrm{C}$ ではイオン状シリカの濃度減少にはさほど差は

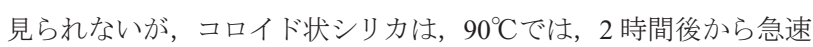
に減少していることがわかる。このことから, pH4 では溶液の温度 は，コロイド状シリカの濃度に大きく影響を与えることがわかる。

(2) $\mathrm{pH}$ の影響Ｆig. 9,10 に溶液の pH が，シリカ濃度に及ぼす 影響について示す。pH1-3では，イオン状シリカ及びコロイド状 シリカ濃度の経時変化に差は見られないが, $\mathrm{pH} 4$ ではイオン状シ リカ, コロイド状シリカともに時間の経過にともない濃度が急激 に低下している。

\section{$3 \cdot 3$ 共存する金属元素の影響}

これまでは, 金属不純物を含まない溶液を用いて検討を行った。 しかし, 実操業では, 精鉱中に含まれる他の不純物が共存する。 そこで，共存元素がシリカの沈殿反応に及ぼす影響を調查した。 元素は，通常の亜鉛製錬工程の溶解液中に比較的高濃度で存在す る $\mathrm{Fe}, \mathrm{Al}, \mathrm{Mg}, \mathrm{Mn}, \mathrm{Ca} の 5$ 種類を選択した。

(1) Fe 添加の影響Ｆig. 11 に Fe $1000 \mathrm{mg} / \mathrm{L}$ となるように添 加した際の固体シリカ濃度の経時変化を示す。 $\mathrm{pH} 1,2$ では, 変化 が見られないが, pH3 では若干量ではあるが固体シリカの生成量 が増加していることがわかる。また Fig. 12 からわかるように, $\mathrm{pH} 3$ では Fe の濃度が大きく減少している。このことから Fe が加 水分解反応によって沈殿する際にシリカを共沈したためであると 考えられる。

(2) Al 添加の影響Ｆig. 13 に $\mathrm{pH} 3$ において $\mathrm{Al}$ を $1000 \mathrm{mg} / \mathrm{L}$ 及 び $5000 \mathrm{mg} / \mathrm{L}$ 添加したときの固体シリカ濃度の経時変化を, 


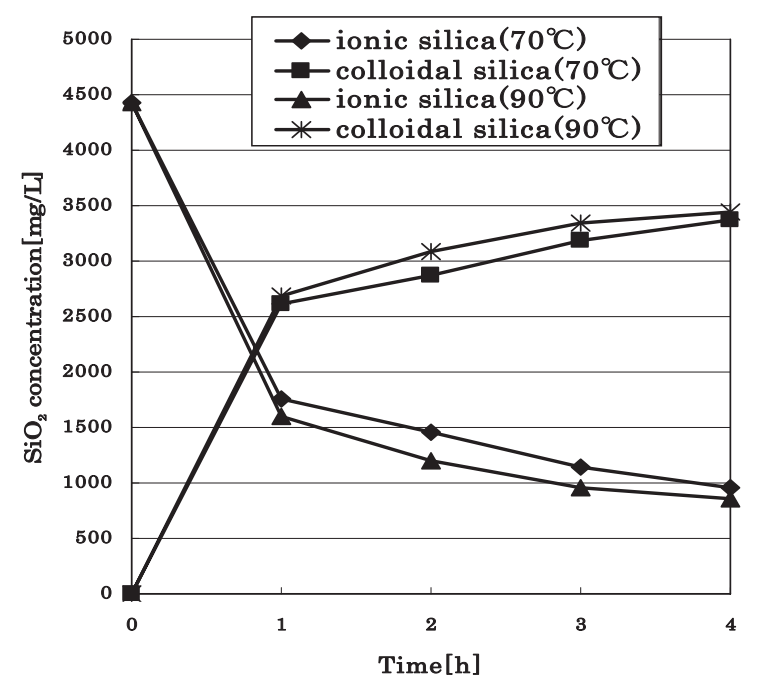

Fig.7 Time-dependence of ionic or colloidal $\mathrm{SiO}_{2}$ concentration at $\mathrm{pH} 3$. Initial $\mathrm{SiO}_{2}$ concentration : $4500 \mathrm{mg} / \mathrm{L}$

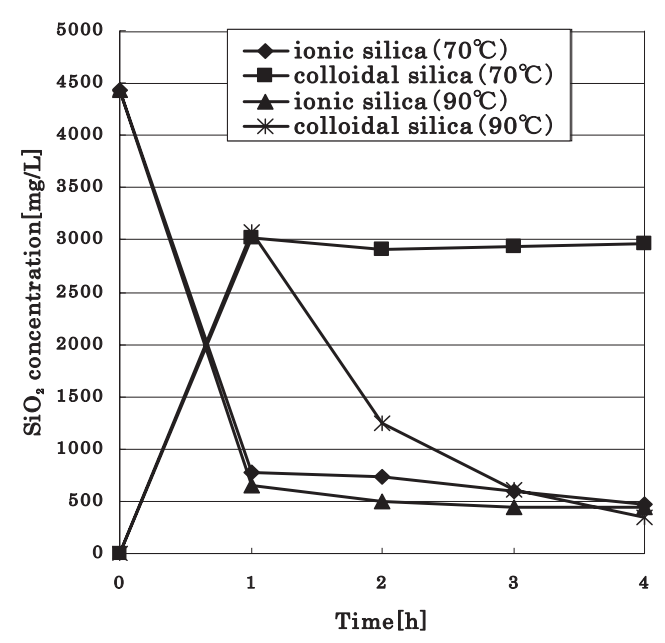

Fig.8 Time-dependence of ionic or colloidal $\mathrm{SiO}_{2}$ concentration at $\mathrm{pH} 4$.

Initial $\mathrm{SiO}_{2}$ concentration : $4500 \mathrm{mg} / \mathrm{L}$

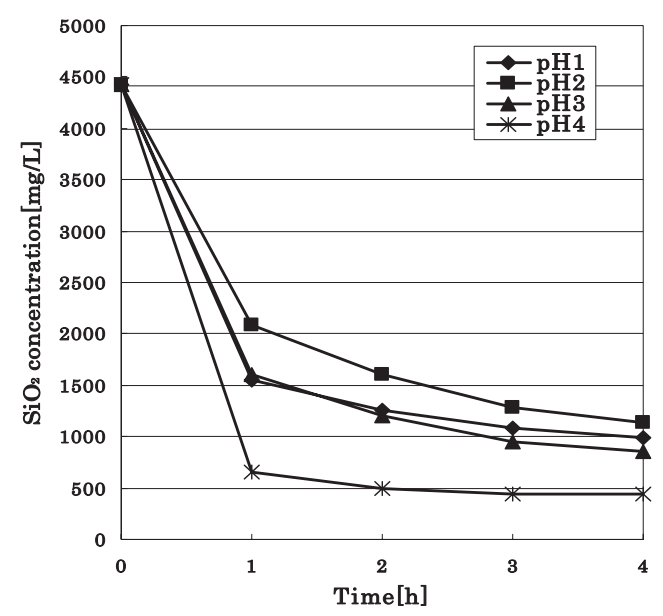

Fig.9 Effect of $\mathrm{pH}$ on the time-dependence of ionic $\mathrm{SiO}_{2}$ concentration at $90^{\circ} \mathrm{C}$

Initial $\mathrm{SiO}_{2}$ concentration: $4500 \mathrm{mg} / \mathrm{L}$

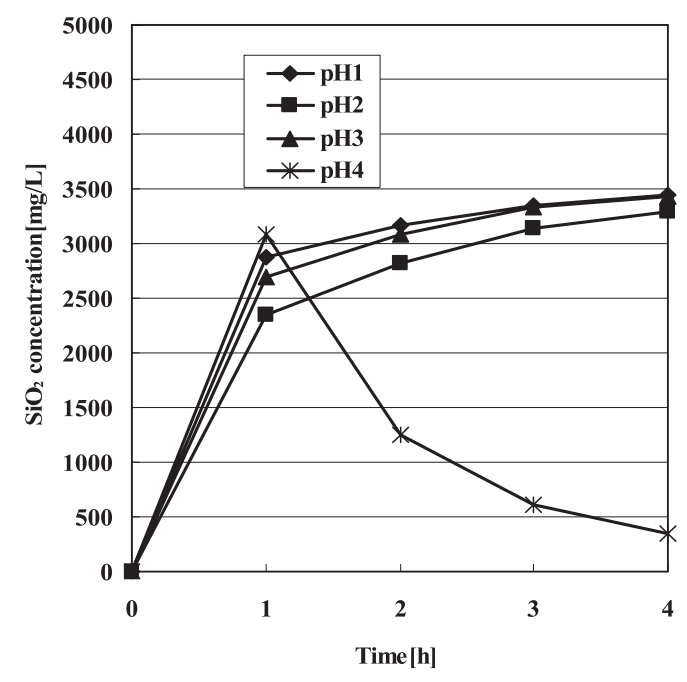

Fig.10 Effect of pH on the time-dependence of colloidal $\mathrm{SiO}_{2}$ concentration at $90^{\circ} \mathrm{C}$.

Initial $\mathrm{SiO}_{2}$ concentration : $4500 \mathrm{mg} / \mathrm{L}$

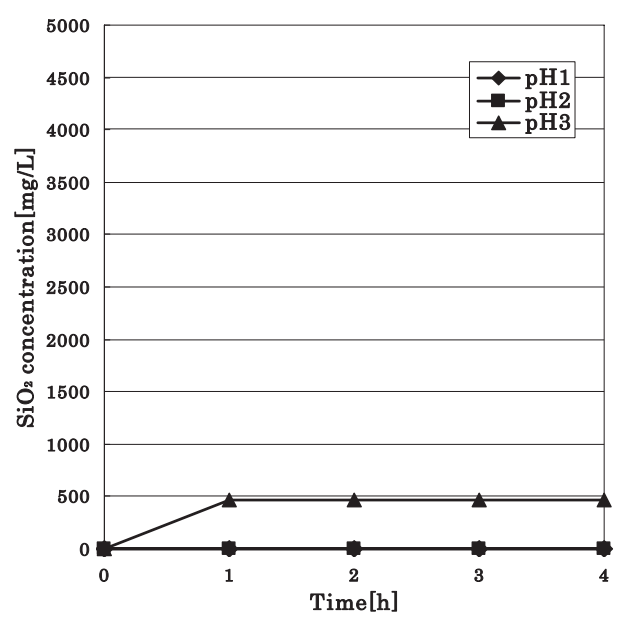

Fig.11 Effect of $\mathrm{pH}$ on the time-dependence of solid $\mathrm{SiO}_{2}$ concentration in the solution containing $1000 \mathrm{mg} / \mathrm{L}$ Fe at $70^{\circ} \mathrm{C}$.

Initial $\mathrm{SiO}_{2}$ concentration : $4500 \mathrm{mg} / \mathrm{L}$

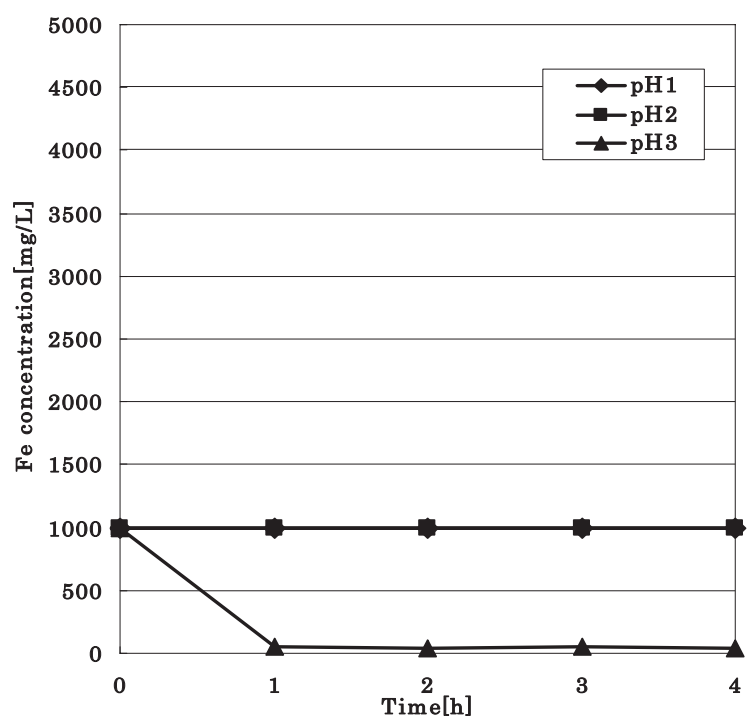

Fig.12 Effect of pH on the time-dependence of Fe concentration in the solution containing $1000 \mathrm{mg} / \mathrm{L} \mathrm{Fe}$ at $70^{\circ} \mathrm{C}$

Initial $\mathrm{SiO}_{2}$ concentration : $4500 \mathrm{mg} / \mathrm{L}$ 


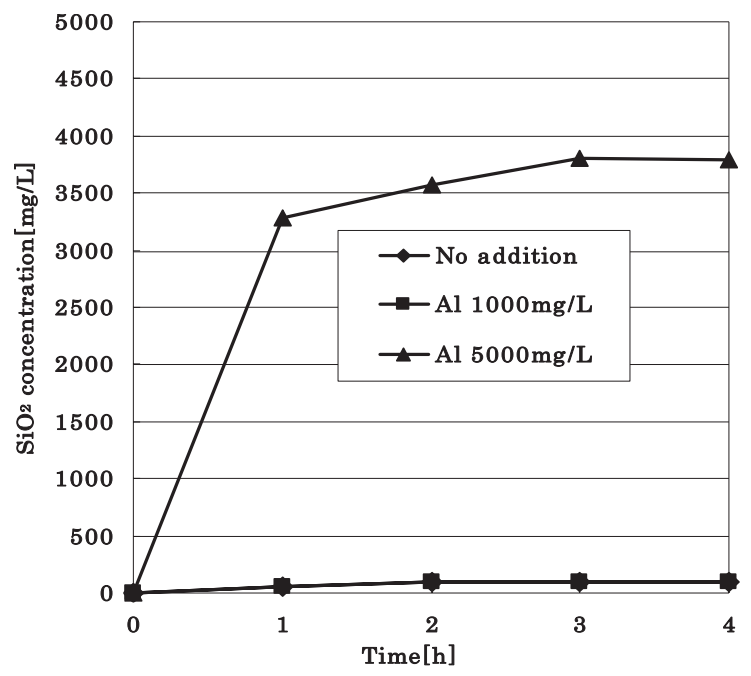

Fig.13 Effect of $\mathrm{Al}$ addition on the time-dependence of solid $\mathrm{SiO}_{2}$ concentration in the solution of $\mathrm{pH} 3.0$ at $70^{\circ} \mathrm{C}$.

Initial $\mathrm{SiO}_{2}$ concentration : $4500 \mathrm{mg} / \mathrm{L}$

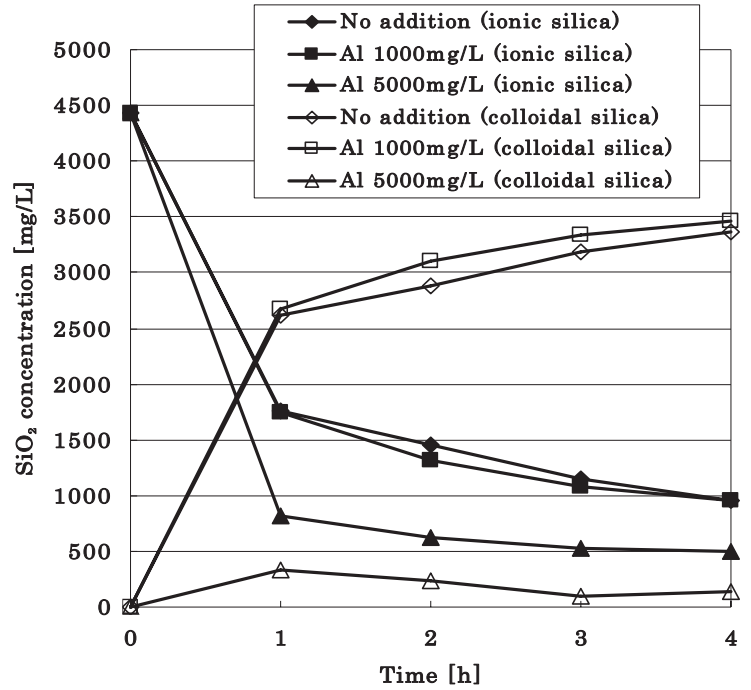

Fig.14 Effect of $\mathrm{Al}$ addition on the time-dependence of ionic or colloidal $\mathrm{SiO}_{2}$ concentration in the solution of $\mathrm{pH} 3.0$ at $70^{\circ} \mathrm{C}$. Initial $\mathrm{SiO}_{2}$ concentration : $4500 \mathrm{mg} / \mathrm{L}$

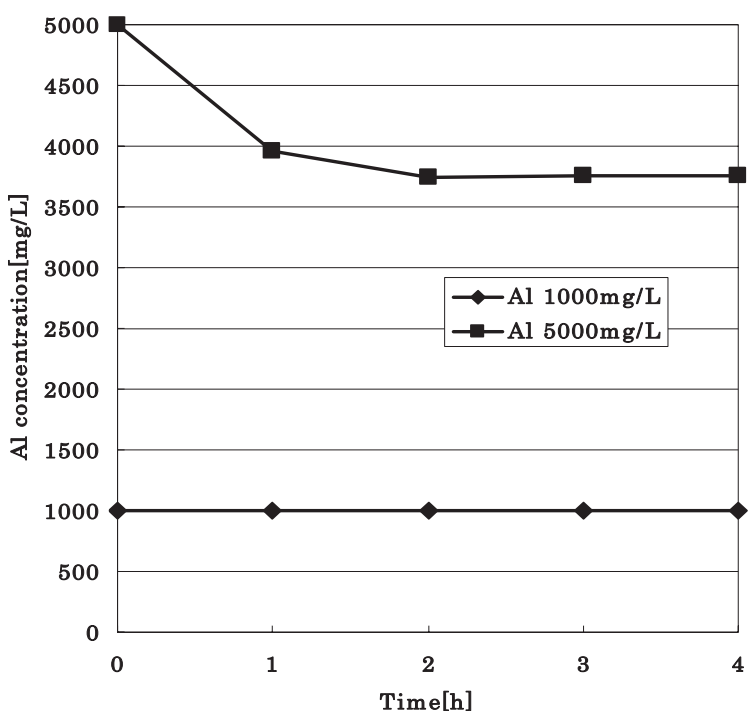

Fig.15 Time-dependence of $\mathrm{Al}$ concentration in the solution of $\mathrm{pH} 3.0$ at $70^{\circ} \mathrm{C}$. Initial $\mathrm{SiO}_{2}$ concentration : $4500 \mathrm{mg} / \mathrm{L}$

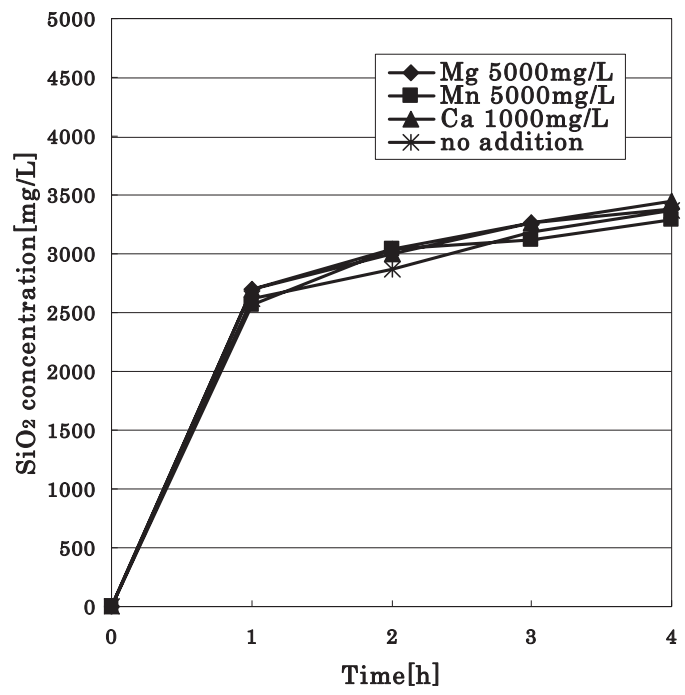

Fig.16 Effect of $\mathrm{Mg}, \mathrm{Mn}, \mathrm{Ca}$ addition on the time-dependence of colloidal $\mathrm{SiO}_{2}$ concentration in the solution of $\mathrm{pH} 3.0$ at $70^{\circ} \mathrm{C}$. Initial $\mathrm{SiO}_{2}$ concentration : $4500 \mathrm{mg} / \mathrm{L}$

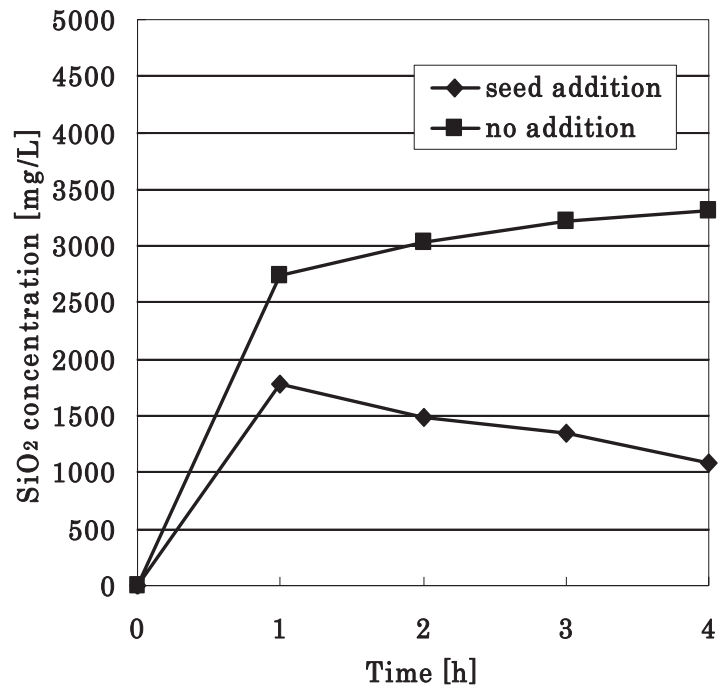

Fig.17 Effect of the addition of solid silica on the time-dependence of colloidal $\mathrm{SiO}_{2}$ concentration in the solution of $\mathrm{pH} 1.0$ at $70^{\circ} \mathrm{C}$. Initial $\mathrm{SiO}_{2}$ concentration : $4500 \mathrm{mg} / \mathrm{L}$

Fig. 14 にイオン状シリカ, コロイド状シリカの経時変化をそれ ぞれ示す。 $\mathrm{pH} 1,2$ では各種シリカ濃度の経時変化に $\mathrm{Al}$ 添加の影 響は見られなかったため，その結果は省略した。 $\mathrm{pH} 3$ では $\mathrm{Al}$ を $1000 \mathrm{mg} / \mathrm{L}$ 添加した場合は各種シリカ濃度の変化は無添加の場合 とほぼ変わらないが， $\mathrm{Al}$ を $5000 \mathrm{mg} / \mathrm{L}$ 添加した場合はイオン状シ リカが急激に減少し，コロイド状シリカがさほど増加寸ることも なく固体シリカが多量に生成している。Fig. 15 に示すように $\mathrm{Al}$ を $5000 \mathrm{mg} / \mathrm{L}$ 添加した場合は, $\mathrm{Al}$ の濃度が約 $1000 \mathrm{mg} / \mathrm{L}$ 減少して いることから, 前述の $\mathrm{Fe}$ 添加の場合と同じように $\mathrm{Al}$ の加水分解 反応による共沈が起ったと考えられる。また, $\mathrm{A} 11 \mathrm{~mol}$ 当りの $\mathrm{SiO}_{2}$ の共沈量は, $1.35 \mathrm{~mol}$ に対し, $\mathrm{Fe} 1 \mathrm{~mol}$ 当りの $\mathrm{SiO}_{2}$ の共沈量は, $0.47 \mathrm{~mol}$ であり, Al の共沈能力が高いことがわかった。

(3) Mg,Mn,Ca 添加の影響Ｆig. 16 に $\mathrm{pH} 3$ において $\mathrm{Mg}$ を $5000 \mathrm{mg} / \mathrm{L}, \mathrm{Mn}$ を $5000 \mathrm{mg} / \mathrm{L}, \mathrm{Ca}$ を $1000 \mathrm{mg} / \mathrm{L}$ それぞれ添加した際 のコロイド状シリカ濃度の経時変化を示す。図よりシリカ濃度の 推移は寸べて無添加の場合とほぼ変わらないことから, これらの 金属イオンはシリカの重合に対する影響はないと考えられる。イ 
オン状シリカ濃度も影響を受けなかった。

\section{$3 \cdot 4$ 固体シリカ添加の影響}

Fig. 17 に pH1 において固体シリカを添加した際のコロイド状 シリカ濃度の経時変化に対する影響について示す。無添加の場合 と比較するとコロイド状シリカが減少していることがわかる。イ オン状シリカ濃度の経時変化も同様の傾向を示した。これはイオ ン状シリカ，コロイド状シリカが吸着作用によって溶液中から除 去されたためと考えられる。また，固体シリカの添加は $\mathrm{pH} 2,3$ においても同様に溶液中のシリカ除去に対して非常に効果的で あった。

\section{4. 結}

\section{言}

本実験を行った結果，以下の知見が得られた。

(1) Janderの提唱したモデルを用いた解析により， $\mathrm{Zn}_{2} \mathrm{SiO}_{4}$ への反 応の見掛けの活性化エネルギーは約 $231 \mathrm{~kJ} / \mathrm{mol}$ であることが わかった。
(2) 溶液の温度はコロイド状シリカの濃度に大きく影響を与え, 温度が高い方がシリカ濃度の低減が促進する。

(3) 溶液の $\mathrm{pH}$ が 1 3 3 ではシリカ濃度の経時変化に差は見られず, $\mathrm{pH} 4$ でシリカ濃度は，大きく減少する。

(4) 実操業における $\mathrm{pH}$ 上昇によるシリカ濃度の減少には $\mathrm{Fe}$ や $\mathrm{Al}$ の加水分解反応による共沈が影響していると考えられる。ま た， $\mathrm{Al}(\mathrm{OH})_{3}$ の方が $\mathrm{Fe}(\mathrm{OH})_{3}$ よりも共沈効果が大きいこと がわかった。一方 $\mathrm{Mg}, \mathrm{Mn}, \mathrm{Ca}$ などの影響はほとんど受けない。

(5) 固体シリカの添加は $\mathrm{pH}$ に関係なく, イオン状シリカ, コロイ ド状シリカ両方の吸着除去に非常に効果的である。

\section{References}

1) Matthews I.G.and Elsner D.: U. S. Patent 3, 656, 941, (1972).

2) Fugleberg,S.P., and Poijarvi: U. S. Patent $4,148,862$ (1979).

3) Radino,H.L.,: Aust Patent. 224. 195, 31 (1957).

4) Bodson, F. J. J.: U.S.Patent 3, 954, 937, 4 (1976).

5) S.Ikenobu and K. Shimokawa: Aust Patent. Application Au-A-36886 (1997)

6) S.Ikenobu: Lead-Zinc 2000 PA, ( USA; 22-25 Oct. 2000.), pp. 427-435

7) JANDER, W. E Z.: anorg. allgem. Chem., 163 (1927), 1-30. 